International Journal of Social Science and Economic Research

ISSN: 2455-8834

Volume: 05, Issue: 05 "May 2020"

\title{
FREE TO GROW: AN OVERVIEW OF THE WATER CRISIS IN RAJASTHAN
}

\author{
Vanshika and Varnika Kalani \\ Sophia Girls Senior Secondary School, Kota, Rajasthan
}

DOI: 10.46609/IJSSER.2020.v05i05.017 URL:https://doi.org/10.46609/IJSSER.2020.v05i05.017

\section{ABSTRACT}

The supply of clean and freshwater to populations that are often demographically and geographically diverse has always been a challenge for policymakers in developing countries. The efficiency of public water management determines the socio-economic mobility of individuals and the economic productivity and activity in the region in general. The frequency of water shortages in India has increased over the past decade. However, one of the most acute water crisis in the country is faced by Rajasthan, a state that occupies 10.4 percent of India hosts $5.6 \%$ of the country's population, but only possesses $1 \%$ of the total surface water resources. This paper has examined the nature of water supply and demand in Rajasthan and has determined that the groundwater levels in Rajasthan have reduced to alarming levels. This lack of access to water affects women and members of 'backward' castes most severely- since the task of water procurement takes away the ability to access drivers of emancipation and socioeconomic mobility such as education. This paper has looked into the effectiveness of central and state Water Policies and has found that contextualization of policies and engagement with stakeholders is imperative to ensure tangible changes on the ground. Lastly, this paper has sought to provide policy recommendations to improve the present water crisis in Rajasthan- centered around the management of water demand and increased collaboration between public and private organizations.

Keywords: Water Crisis, Water resources, Drinking water, Water management, Rajasthan

\section{INTRODUCTION}

In liberal democracies, regular access to fresh water is considered to be a necessity because it is imperative for personal care and sustenance, commercial agriculture, and other industrial production that sustains the modern economy. The availability of water resources in any 


\section{International Journal of Social Science and Economic Research}

ISSN: $2455-8834$

Volume: 05, Issue: 05 "May 2020"

particular region along with the water management policies of the local government determines the socio-economic development of that region to a large extent. This is true not only because the industrial and agricultural activity is contingent of the availability of water but also because the collective effort directed to satisfy the community's need for water reduces the propensity of people to engage in other activities that dictate personal and social development- such as education and training. There has been a steady rise in the demand for and usage of water in developing countries that are usually characterized by an emerging economy and a rapidly growing population. A report by the UN World Water Development published in 2019 notes that about 4 billion people, representing nearly two-thirds of the world population, experience severe water scarcity during at least one month of the year (UNESDOC, 2019). The management of water resources and the provision of freshwater to the population has become one of the most pressing challenges for policymakers across the developing world. Countries like India and Pakistan have been rapidly depleting their groundwater resources. The contamination of groundwater and freshwater resources has further reduced their ability to meet the demand for water in the future (Mekonnen \& Hoekstra, 2016).

Rajasthan is the largest state in India and makes up for more than $10 \%$ of the country's territory. It's estimated population of more than 56 million individuals is sparsely spread over its 41,538 villages. Even though deserts cover a significant portion of the area of Rajasthan, the economy of the state is primarily based on agriculture and animal husbandry. $90 \%$ of Rajasthan's population is dependent on groundwater for drinking and irrigation purposes- which puts immense pressure on groundwater resources of the state (Drew, et. al., 2016). Rajasthan is the most water-deficient state in India owing to extremely short spells of monsoon coupled with erratic behavior and scanty rainfall. Drought is the most frequent and recurring natural disaster in the state. Successive years of drought between 2010-2015 have eroded natural resources which have, in turn, led to the reduction in the agricultural capacity of the land and the economic potential and productivity of people. All the 32 districts (41000 villages) of the state have been declared to be affected by droughts- which has severely impacted the ability of the poorest communities in the country to afford commodities necessary for sustenance including safe drinking water and adequate nutrition. Family food security has been under threat due to considerable economic losses, and reduced agriculture output which has forced the rural poor to migrate to urban centers such as Jaipur and Jodhpur- in search of a livelihood and to avoid increased risks and vulnerability caused by drought (Drew, et. al., 2016).

The lack of access to freshwater has hampered women's empowerment in Rajasthan- a state that has historically performed poorly in its pursuit of achieving gender equality since it suffers from low rates of literacy amongst women and the prevalence of child marriage- despite legal and policy interventions by the state. Women in Rajasthani families are burdened with managing 


\section{International Journal of Social Science and Economic Research}

ISSN: $2455-8834$

Volume: 05, Issue: 05 "May 2020"

water resources for the entire family. This takes up a significant part of the day and reduces the ability of women to join schools or take up other sources of employment, hence hampering their socio-economic mobility and self-actualizing ability. Moreover, the lack of availability of clean water increases the propensity of transmission of diseases such as diarrhea, cholera dysentery, typhoid, and polio (WHO, 2019). Water management and state intervention have not been sufficient to meet the demand for water. There is a need to increase efficiency in the process of water supply and reduce the demand for water through the adoption of sustainable practices to reduce the effect of the water crisis faced by Rajasthan today.

\section{BACKGROUND}

The demographics, geography, and economy of Rajasthan are key factors that have increased the pressure on water supply in the state over the past few decades. The population of Rajasthan grew from 10 million in 1901 to 16 million in 1951, but from 1951 to 2011 it grew about four and a quarter times to 68.5 million (WAPCOS, 2014). According to the Census of India conducted in 2011, Rajasthan has continued to maintain its record of registering one of the highest population growth rates in the country. The annual population growth rate of Rajasthan stood at 2.13 percent, which is around 30\% higher than the national average (Census of India, 2011). Moreover, the growth rate has doubled in a period of fewer than 29 years since 1951 . Acceleration in the population growth rate can be attributed to improvements in the public health infrastructure- that has led to a reduction in the death and infant mortality rate and has, in turn, positively impacted the birth rate in the state. The desert districts of Barmer, Jaisalmer, Jodhpur, Jalore, and Bikaner- where there exists a high pressure on water supply, have attained higher population growth rates ranging from $24.28 \%$ to $32.52 \%$ (WAPCOS, 2014). Even though the population of Rajasthan is growing at a high rate, the population density continues to be very low. More than almost half of all the inhabited villages in the State have fewer than 500 inhabitants each (WAPCOS, 2014). Connecting different villages to water supply lines has historically been a challenge for public officials and policymakers. Even though Rajasthan occupies 10.4 percent of India and is home to $5.6 \%$ of the country's population, it only possesses $1 \%$ of the total surface water resources of India, hence making the resource more scarce than it is in the rest of the country (Singh, et. al., 2013).

Rajasthan's economy is primarily agricultural and pastoral. The economy of Rajasthan is sustained by the mass cultivation of wheat, barley, oilseeds, and sugarcane. However, due to the lack of development of irrigational facilities, agricultural activity and production are dependent on the monsoon rains, which are often erratic and unpredictable. More than $80 \%$ of rural families in Rajasthan keep livestock in their households and the contribution of the animal husbandry to the GDP of the State has been estimated to be around 9.16\% (Singh, et. al., 2013). About 35\% of 


\section{International Journal of Social Science and Economic Research}

ISSN: $2455-8834$

Volume: 05, Issue: 05 "May 2020"

the income to small and marginal farmers comes from dairy and animal husbandry. The absence of hydropower plants in Rajasthan has led to increased dependency in thermal power productionwhich requires a continuous supply of water to act as a coolant. The lack of public infrastructure that facilitates water management and distribution combined with the water-intensive economic activity of Rajasthan and unpredictable monsoon rains has led to unchecked exploitation of groundwater resources.

A study was undertaken to analyze the water burden on Jaisalmer and Sri Ganga Nagar- two regions in Rajasthan revealed that the water burden could be categorized based on settlement patterns of villages. 'Gaanvs', areas with denser populations use tube wells located in the vicinity of those settlements whereas the women of dhaanis- areas with a low population density often spend hours attempting to collect water from open dry wells (Drew, et. al., 2016). The distance of 'gaanvs' to water sources was calculated to be between 100-200 meters and that to 'dhaanis' was calculated to be between 2-3 kilometers. (Drew, et. al., 2016). The economic productivity of rural Rajasthan and the sustenance of landless farmers and agricultural laborers are often a product of the availability of water resources used in irrigation and animal husbandry.

\section{DISCUSSION}

The variability of monsoons, combined with a growing population and need for economic activity has led to a water crisis in Rajasthan - with water shortages reaching alarming proportions in some parts of the state. The overexploitation of groundwater and lack of dilution though recharge has resulted in the degradation of groundwater quality and quantity in many parts of the state. The water supply systems of many towns, villages, and habitations have been put under great strain due to the reduction in yield from hand pumps, tube wells, and open wells. Research suggests that the groundwater of $25 \%$ of villages in the state is contaminated by the presence of high levels of fluoride- a problem that is expected to affect $50 \%$ of the villages in the next decades, primarily due to the growing variability in rainfall and the indiscriminate exploitation of groundwater. The Accelerated Rural Water Supply Programme (ARSWP)was introduced in 1973 by the government of India to assist states and union territories in accelerating the pace of coverage of drinking water supply (Mondal, 2019). It aimed to provide all rural habitations, government schools, and anganwadis access to safe drinking water. However, only $44 \%$ of rural households and $85 \%$ of government schools and anganwadis have been provided access by 2017 (PRS, 2017). It also aimed to provide $50 \%$ of the rural population potable drinking water amounting to 55 liters per individual every day by developing a system of piped water supply. It also sought to provide freshwater connections to $35 \%$ of rural households. However, only $18 \%$ of the rural population was provided potable drinking water and only $17 \%$ of rural households were given household connections(PRS, 2017). Rajasthan is one of the worst 


\section{International Journal of Social Science and Economic Research}

ISSN: $2455-8834$

Volume: 05, Issue: 05 "May 2020"

performers when it comes to implementing the ARSWP. In Sriganganagar district, the Public Health Engineering Department (PHED) has installed only 2132 hand pumps, which is expected to be insufficient in fulfilling the demand for water. Moreover, according to the report of PHED, only 593 of 2132 were functioning on the ground. The failure of state policy is primarily due to the combination of the lack of contextualization of public policy and the restriction policy to water supply.

The population density of settlements in Rajasthan is an important factor that affects the demand for water; with high pressure on water resources affecting not only per capita water availability but also the quality of water at the source. Poverty is an aggravator of water-related stress, given the inability of poor households to invest in water collection, storage, and purification. Additionally, caste continues to play a role in determining access to water in villages- with members of the scheduled caste community being denied access to clean water from tube wells and wells due to social ostracization (Government of Rajasthan, 2018). The ignorant attitude of public officials towards caste-based discrimination has based exasperated the problem of availability of clean water to most oppressed communities. Communities in Rajasthan follow strict patriarchal norms which make women the worst victims of the perpetual water shortage. Women, being straight-jacketed into the role of being 'homemakers' are made to bear the responsibility of collecting transporting, storing, providing and managing water. In places, where there is no water for farming, men migrate to urban areas in search of work leaving women behind to fend for themselves, the elderly and children. Women are forced to spend most of their time collecting water from distant sources, which reduces their ability to engage in productive work or education. This has contributed to Rajasthan having the lowest female literacy rate in India at just 52.66\% (Balani, 2017). The regular chore of water collection has adverse effects on the health of women, as it increases the chances of contracting water-borne diseases such as Schistosomiasis (bilharzia) and dracunculiasis. The lack of supply of clean freshwater forces individuals to use contaminated water- hence increasing the risk factors of contracting typhoid, cholera, and jaundice (Tebutt, 1998). Research has shown that the drying up of natural water bodies coincides with outbreaks of water-borne diseases and forces women to spend more time procuring water in rural Rajasthan (Drew, et al., 2016)

In the absence of adequate provisions by the central and state government, the women of Rajasthan have been forced to take up the burden of water management and supply upon themselves. 'Water Committees' are informal associations of women that seek to promote conventional methods of water conservation. This includes interventions ranging from the development of rainwater harvesting systems to training individuals to adopt sustainable practices in their day to day activities (Saxena \& Saxena, 2014). However, the impact of these 


\section{International Journal of Social Science and Economic Research}

ISSN: $2455-8834$

Volume: 05, Issue: 05 "May 2020"

committees has been limited due to the paucity of funds and the lack of scientific and technical knowledge and expertise.

\section{CONCLUSION}

The availability of clean water has an impact on the short and long term development of society and the socio-economic mobility of individuals. Water shortages in Rajasthan have the most severe impact on people belonging to historically oppressed and marginalized identities. By reducing the ability of women to seek emancipation and further alienating backward castes from mainstream society- water shortages reduce the ability of oppressed groups to gain social and economic ability. Moreover, the agrarian economy of Rajasthan depends on a continuous supply of water. With depleting groundwater levels, it is the need of the hour to develop a statesponsored water management mechanism. The development of public infrastructure that facilitates the distribution of water to sparsely spread out villages and settlements requires significant levels of investment, which have been absent. Moreover, it is important to contextualize national-level water policies to the social, demographic and geographical environment of Rajasthan to achieve tangible changes on the ground. Working with voluntary 'Women's Committees' and other grassroots level organizations to inculcate sustainable habits amongst the people is considered to be an effective way of regulating water demand.

Rajasthan has witnessed certain improvements over the past 2 years since the introduction of the Rajasthan's Mukhya Mantri Jal Swavlambhan Abhiyan- a state-level multi-stakeholder project that seeks to make the remotest of the villages in the state water-sufficient, by focusing on reviving water bodies, increasing groundwater levels, and providing clean drinking water. This has led to the restoration of $80 \%$ of the irrigation potential of identified water bodies by implementing micro-irrigation technologies through community-managed ponds and tanks (Saini, 2018). The recent success of the Mukhya Mantri Jal Swavlambhan Abhiyan shows the enhanced effectiveness of public policy when it focuses on grassroots level engagement and community galvanization. Despite recent improvements, Rajasthan continues to suffer from a water crisis, the solution to which lies in the combined efforts and engagement between the government, grassroots level NGOs, international organizations and most importantly- the public.

\section{BIBLIOGRAPHY}

Balani, K. Rajasthan: India's seventh largest state, lowest in female literacy. Business Standard, 11th January, 2017 
International Journal of Social Science and Economic Research

ISSN: 2455-8834

Volume: 05, Issue: 05 "May 2020"

Census of India - 2011. Office of the Registrar General \& Census Commissioner, India. Accessed on 20th January 2020

Drew, G., Jalees, K., Pandey, P. (2016). Water Crisis in Rajasthan. National Commission for Women. Accessed on 21st January 2020

Mekonnen, M. \& Hoekstra, A. (2016). Four billion people facing water scarcity. Science Advances. Accessed on 19th January 2020

Mondal, P. (2019). Rajiv Gandhi National Drinking Water Mission. Accessed on 22nd January 2020

PRS (2017). National Rural Drinking Water Programme. PRS Legislative Research, Accessed on 18th January 2020

Saini, S. State shows how to manage water resources, earns NITI Aayog pat. Hindustan Times. 17th June 2018

Saxena, U. and Saxena, S. (2014). Ground water quality evaluation with special reference to Fluoride and Nitrate contamination in Bassi Tehsil of district Jaipur, Rajasthan, India. International Journal Of Environmental Sciences, Accessed on 23rd January 2020

Singh, S., Reddy, R.V., Batchelor, C., Marothia, D.K., James, A.J., Rathore, M.S. (2013). Regulating Water Demand and Use in Rajasthan. European Union State Partnership Programme. Accessed on 20th January 2020

Tebbutt, T. (1998). Principles of Water Quality Control. Elsevier Ltd, Accessed on 15th January 2020

UNESDOC (2019). The United Nations world water development report 2019: Leaving no one behind, facts and figures. Accessed on 16th January 2020

Government of Rajasthan. (2018). Rajasthan: Urban Water Supply Policy. Accessed on 23rd January 2020

WAPCOS (2014). Study on Planning of Water Resources of Rajasthan. Tahal Group. Accessed on 21 st January 2020

World Health Organization. Drinking-Water. 14th June 2020 